\title{
Homosynaptic Long-Term Synaptic Potentiation of the "Winner" Climbing Fiber Synapse in Developing Purkinje Cells
}

\author{
Laurens W. J. Bosman, ${ }^{\star}$ Hajime Takechi, ${ }^{\star}$ Jana Hartmann, Jens Eilers, and Arthur Konnerth \\ Institute of Neuroscience and Center of Integrated Protein Science, Technical University Munich, 80802 Munich, Germany
}

\begin{abstract}
During the developmental formation of neuronal circuits, redundant synapses are eliminated and persisting synapses strengthened. In the immature cerebellum, climbing fiber-Purkinje cell synapses undergo a pronounced synaptic rewiring, from a multiple innervation around birth to a mono-innervation in adults. An early stage of this process consists in the differentiation of initially equally strong synapses into one "large" and several "small" synaptic inputs. By performing whole-cell recordings in Purkinje cells of rat cerebellar slices, we found that the coincident activation of a Purkinje cell and one of its afferent climbing fibers induces homosynaptic long-term synaptic potentiation (LTP). This LTP requires postsynaptic $\mathrm{Ca}^{2+}$ signaling and involves an increase in the single channel conductance of the postsynaptic AMPA receptors. Interestingly, LTP occurs exclusively at large synaptic inputs. It is not observed at small inputs that are eventually eliminated. Thus, we identified a new form of LTP that is expressed uniquely and just for a restricted period of early development in the large climbing fiber inputs. Our results suggest that this LTP mediates the activity-dependent maturation of the "winner" climbing fiber.
\end{abstract}

Key words: cerebellum; climbing fiber; development; LTD; LTP; synaptic plasticity

\section{Introduction}

The cerebellum integrates multiple forms of sensory information and plays a critical role in motor coordination and motor learning (Ito, 2000; Boyden et al., 2004; Krakauer and Shadmehr, 2006). Cerebellar functions are largely determined by the Purkinje cells, which are the output neurons of the cerebellar cortex. Purkinje cells integrate two types of excitatory input, the parallel and the climbing fibers. In adult rodents, each Purkinje cell has $\sim 200,000$ parallel fiber synapses and a single climbing fiber synapse (Eccles et al., 1966; Napper and Harvey, 1988). A parallel fiber synapse is confined to a single dendritic spine. The resulting EPSPs have, thus, only small amplitudes. In contrast, a single climbing fiber has numerous contact sites with the postsynaptic Purkinje cell. Climbing fiber activity, therefore, reliably evokes a large postsynaptic response, the "complex spike," that is pro-

Received Sept. 6, 2007; revised Dec. 4, 2007; accepted Dec. 7, 2007.

This work was supported by grants from the Deutsche Forschungsgemeinschaft to A.K. and J.H. and by a TALENTstipend from The Netherlands Organization for Scientific Research to L.W.J.B. We thank Irene Schneider, Roswitha Maul, Susanne Schickle, and Ines Mühlhahn for excellent technical assistance. We are grateful to Masanobu Kano, Christian Hansel, and Thomas Misgeld for critically reading this manuscript.

*L.W.J.B. and H.T. contributed equally to this work.

Correspondence should be addressed to Arthur Konnerth, Institute of Neuroscience, Technical University Munich, Biedersteiner Strasse 29, 80802 Munich, Germany. E-mail: arthur.konnerth@|rz.tu-muenchen.de.

L. W. J. Bosman's present address: Department of Neuroscience, Erasmus Medical Center, 3000 CA Rotterdam, The Netherlands.

H. Takechi's present address: Department of Geriatric Medicine, Graduate School of Medicine, Kyoto University, 606-8507 Kyoto, Japan.

J. Eilers' present address: Carl Ludwig Institute of Physiology, Leipzig University, 04103 Leipzig, Germany. D01:10.1523/JNEUROSCI.4074-07.2008

Copyright $\odot 2008$ Society for Neuroscience $\quad$ 0270-6474/08/280798-10\$15.00/0 duced by a large synaptic current (Larramendi and Victor, 1967; Llinás et al., 1969; Konnerth et al., 1990).

Long-term depression (LTD) of parallel fiber-Purkinje cell inputs is produced by repetitive stimulations of both parallel and climbing fiber synapses (Ekerot and Kano, 1985; Ito, 2001). It is considered to be the primary cellular mechanism of cerebellar motor learning (Marr, 1969; Albus, 1971; Koekkoek et al., 2003). More recently, parallel fiber long-term synaptic potentiation (LTP) has been described previously (Salin et al., 1996; Lev-Ram et al., 2002; Coesmans et al., 2004). Climbing fiber LTD has been first reported by Hansel and Linden (2000) in young rats [postnatal day 14 (P14)-P22].

Purkinje cells and their afferent climbing fiber inputs undergo a striking process of synaptic reorganization during the first 2-3 weeks of postnatal development. In rats, at the end of the first postnatal week, on average three to four climbing fibers of similar strength converge on each Purkinje cell soma (Crepel et al., 1981; Mariani and Changeux, 1981). In parallel to the growth of the Purkinje cell dendritic tree, the synapses of all but one climbing fiber are eliminated by the end of the third postnatal week (Crepel et al., 1981; Hashimoto and Kano, 2003; Ito, 2006). Aberrant persisting multiple climbing fiber innervation of mature Purkinje cells is accompanied by severe ataxia (Goda and Davis, 2003). Many of the molecular cues controlling climbing fiber elimination have been identified (for review, see Hashimoto and Kano, 2005). Interestingly, activity of parallel fibers is required for the proper development of climbing fiber-Purkinje cell synapses (Crepel et al., 1981; Rabacchi et al., 1992; Scelfo and Strata, 2005). It is unclear, however, whether the activity of the climbing fibers 

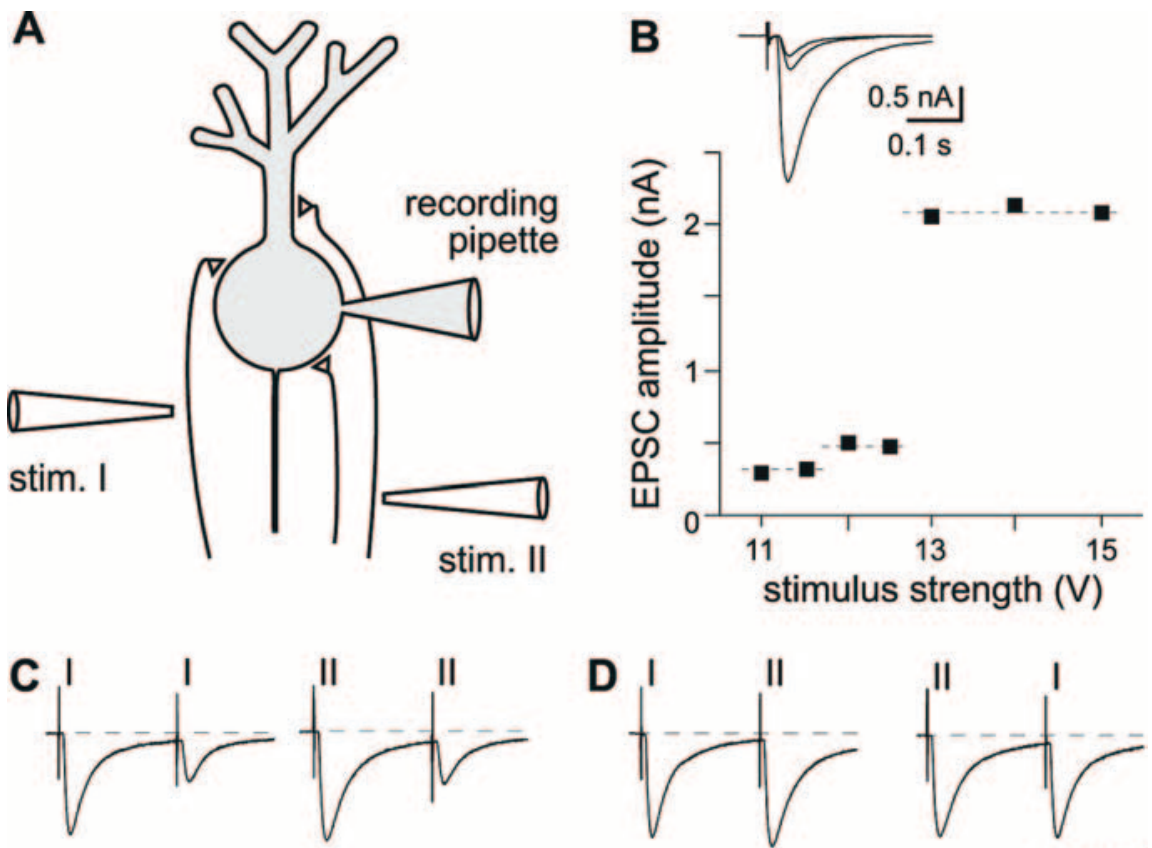

Figure 1. Identification of climbing fiber inputs in the immature cerebellum. $\boldsymbol{A}$, Schematic diagram of the experimental arrangement. Climbing fiber EPSCs were recorded from Purkinje cells in the whole-cell voltage-clamp configuration. For each Purkinje cell tested, the climbing fiber inputs were stimulated at two positions (stim. I and stim. II) in the granular layer. $\boldsymbol{B}$, Stepwise recruitment of up to three climbing fibers by increasing the stimulation strength at a fixed stimulation site. The dashed lines represent the mean amplitude of the discrete steps. The corresponding EPSCs are shown superimposed in the inset. $\boldsymbol{C}$, Paired-pulse depression of the EPSC amplitudes of two independently activated climbing fiber inputs (I and II). D, Sequential activation of both inputs produced no depression confirming the selective activation of distinct climbing fiber synapses. Representative examples from postnatal day 7 in $\boldsymbol{B}$ and postnatal day 6 in $\boldsymbol{C}$ and $\boldsymbol{D}$.

themselves is in any way important for synaptic maturation. For example, an intriguing question remains whether the presumed neonatal presence of NMDA receptors (Garthwaite et al., 1987; Krupa and Crepel, 1990; Rosenmund et al., 1992) controls the development of climbing fiber synapses. NMDA receptormediated calcium entry is known to underlie the induction of many types of long-term synaptic plasticity in other brain regions (Bliss and Collingridge, 1993; Nicoll, 2003). Of particular interest are the mechanisms of synaptic plasticity in the first week of postnatal development, a period during which multiple climbing fibers provide a strong synaptic input to soma, whereas the impact of the parallel fiber system is still weak. These questions prompted us to investigate activity-dependent synaptic plasticity at climbing fiber-Purkinje cell synapses during their "hottest" stage of synaptic rearrangement.

\section{Materials and Methods}

Tissue preparation. Parasagittal cerebellar slices (200-300 $\mu \mathrm{m}$ thick) were prepared from 4- to 11-d old Wistar rats (Charles River, Sulzfeld, Germany). The animals were decapitated and their cerebella rapidly removed and placed in artificial CSF (ACSF) containing (in mM) $125 \mathrm{NaCl}$, $2.5 \mathrm{KCl}, 2 \mathrm{CaCl}_{2}, 1 \mathrm{MgCl}_{2}, 1.25 \mathrm{NaH}_{2} \mathrm{PO}_{4}, 26 \mathrm{NaHCO}_{3}$ and 20 glucose, carboxygenated with $95 \% \mathrm{O}_{2}$ and $5 \% \mathrm{CO}_{2}\left(<4^{\circ} \mathrm{C}\right)$. Slices were cut using a vibratome slicer (Leica, Wetzlar, Germany) and stored for $1 \mathrm{~h}$ at $35^{\circ} \mathrm{C}$ and then for up to $8 \mathrm{~h}$ at room temperature in carboxygenated ACSF.

Whole-cell recordings. Somatic whole-cell recordings were obtained with either an EPC9 (HEKA, Lambrecht, Germany) or a BVC-700A amplifier (Dagan, Minneapolis, MN) using Pulse software (HEKA). Pipettes (2-4 M $\Omega$ ) were pulled from borosilicate glass (Hilgenberg, Malsfeld, Germany). For standard experiments, the pipette solution comprised of

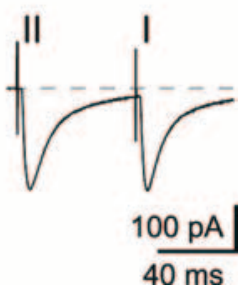

(in $\mathrm{mM}$ ) 135 Cs-gluconate, 0.6 EGTA, 10 HEPES, 20 TEA, $2 \mathrm{MgCl}_{2}$, $4 \mathrm{Mg}$-ATP, and 0.4 $\mathrm{Na}-\mathrm{GTP}, \mathrm{pH}$ 7.3. In indicated experiments, 10 or $20 \mathrm{~mm}$ BAPTA replaced 20 or $40 \mathrm{~mm}$ Csgluconate. For combined fluorometric and electrophysiological recordings, the pipette solution contained (in $\mathrm{mm}$ ) $148 \mathrm{~K}$-gluconate, 10 HEPES, $10 \mathrm{NaCl}, 0.5 \mathrm{MgCl}_{2}, 4 \mathrm{Mg}$-ATP, $0.4 \mathrm{Na}-\mathrm{GTP}$, and 0.025-0.1 Oregon green BAPTA-1 (Invitrogen, Eugene, OR), pH 7.3. The latter pipette solution was also used for the experiments in which the LTP/LTD induction was under current-clamp. During the experiments, the slices were continuously perfused with ACSF at room temperature (unless indicated otherwise), to which $10 \mu \mathrm{M}$ bicuculline-methiodide (Sigma, Deisenhofen, Germany) was added.

LTP and LTD recordings. Climbing fiber afferents were stimulated for $100 \mu \mathrm{s}$ at 15 or $30 \mathrm{~s}$ intervals, using glass electrodes filled with ACSF placed in the granular layer. When a stable baseline was obtained for 5-10 min, an induction protocol was applied and recordings were continued for 20-30 min thereafter. LTP-inducing stimuli were delivered within $20 \mathrm{~min}$ after the establishment of the whole-cell configuration.

The induction protocols consisted of either, (1) in voltage clamp, $4 \mathrm{~Hz}$ stimulation of a climbing fiber input for $5 \mathrm{~min}$ in conjunction with sustained somatic depolarization (to 0 $\mathrm{mV}$ ) of the Purkinje cell or, (2) in current clamp, $4 \mathrm{~Hz}$ stimulation of a climbing fiber input for $100 \mathrm{~s}$ in conjunction with tandem depolarizations of the Purkinje cell. The Purkinje cell was depolarized just above threshold to trigger an action potential. There was a $20 \mathrm{~ms}$ interval between the two consecutive depolarizations of the tandem stimulation. Experiments involving the second protocol were performed at $33^{\circ} \mathrm{C}$.

Series resistance was monitored throughout the recording, and only stable recordings ( $<20 \%$ change) with a series resistance $<20 \mathrm{M} \Omega$ were included in the analysis.

Confocal fluorescence imaging. Confocal $\mathrm{Ca}^{2+}$ imaging was performed using a confocal laser-scanning microscope (Odyssey; Noran, Middleton, WI) attached to an upright microscope (Axioskop; Zeiss, Wetzlar, Germany) with a $\times 40$ water-immersion objective, NA 0.9. Recordings were made at $60 \mathrm{~Hz}$ (Eilers et al., 1995) and recorded on an optical disk recorder (TQ2026F; Panasonic, Secaucus, NJ). Analysis was performed off-line with Image-1 software (Universal Image, West Chester, PA). The $\mathrm{Ca}^{2+}$-dependent fluorescence from defined regions of interest were background-corrected and expressed as increase in the fluorescence divided by prestimulus fluorescence $(\Delta F / F)$ using Igor Pro software (Wavemetrics, Lake Oswego, OR).

Nonstationary noise analysis. The single channel conductance of the AMPA receptors involved in the climbing fiber EPSCs was calculated using nonstationary noise analysis (Sigworth, 1980; Traynelis et al., 1993). For each experiment, the EPSCs before and after LTP induction were averaged. For this analysis, we have used the data from the "currentclamp" LTP protocol. Records that had a spontaneous event during the decay phase of the climbing fiber EPSC were rejected. Next, the peak amplitude of each EPSC was scaled to the peak amplitude of the mean EPSC. The decay phase of each peak-scaled EPSC was compared with the decay phase of the respective mean EPSC. For each sample point, the squared distance between the individual and the mean EPSC was calculated. For this analysis, we have used the $90 \mathrm{~ms}$ after the peak of the EPSC. Then the means of the squared distances for all EPSCs per sample point were calculated and plotted against the current of the mean EPSC. This distribution was fitted with a parabolar function $\left(\sigma^{2}=V_{\mathrm{b}}+i_{\mathrm{u}}{ }^{*} I-\right.$ 
A
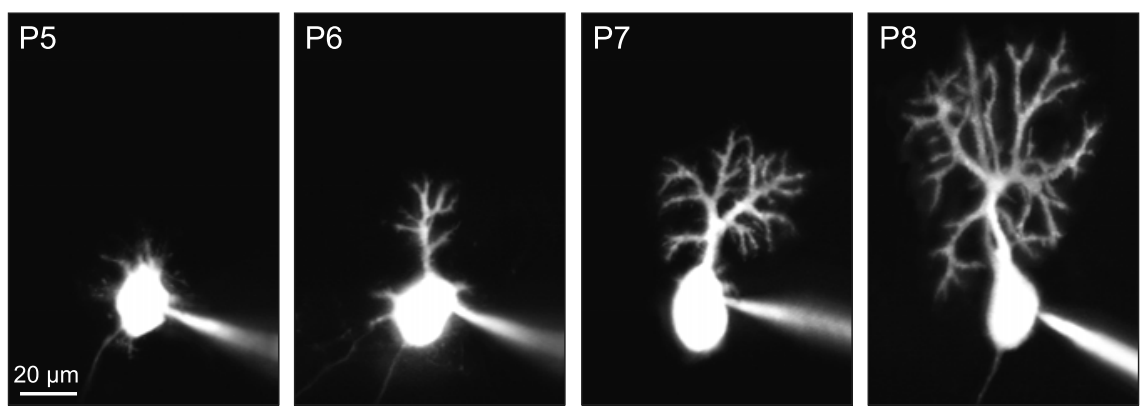

C

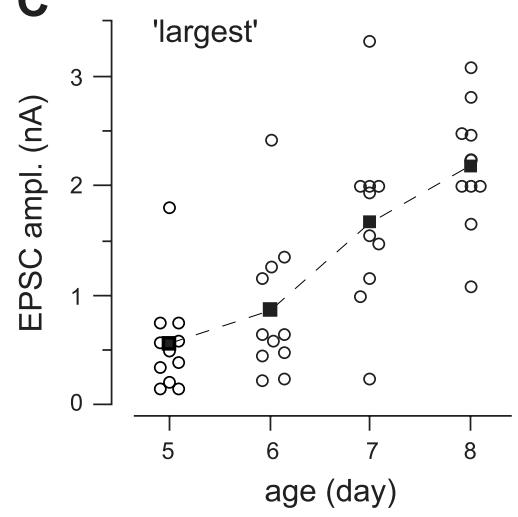

D

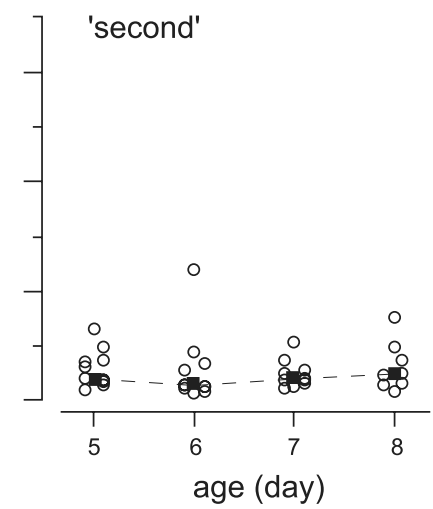

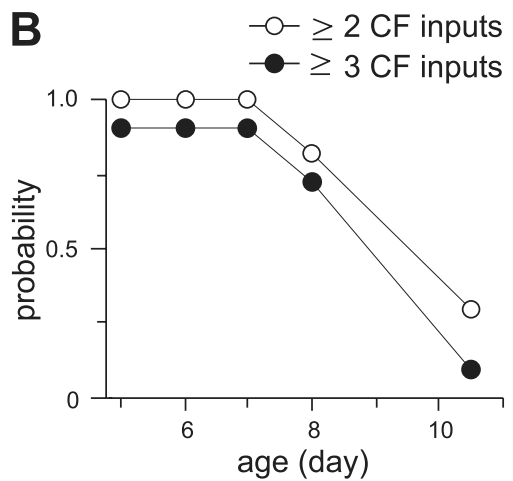

$\mathbf{E}$

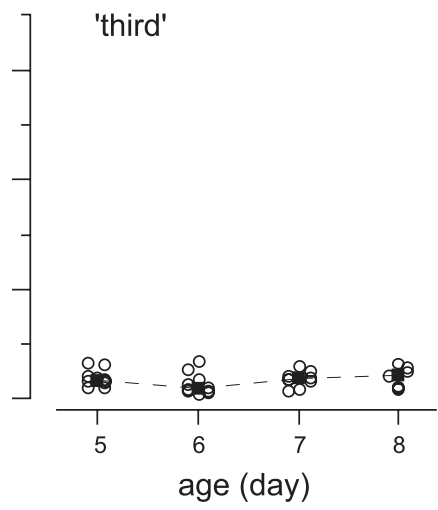

Figure 2. Growth of the Purkinje cell dendritic tree and concomitant increase of the largest climbing fiber input in early postnatal development. $\boldsymbol{A}$, Representative fluorescence images of Purkinje cells (loaded with the $\mathrm{Ca}^{2+}$ indicator dye Oregon green BAPTA-1 through the patch pipette) from P5 to P8. B, Mean number of climbing fiber inputs to a given Purkinje cell from P5 to P11. Each data point represents the average of $n=10$ cells. Data from P10 and P11 were pooled. $\boldsymbol{C}-\boldsymbol{E}$, Peak amplitudes of climbing fiber EPSCs recorded from the largest $(\boldsymbol{C})$, second $(\boldsymbol{D})$, and third $(\boldsymbol{E})$ climbing fiber inputs in Purkinje cells from P5 to P8 (values from at least $n=10$ Purkinje cells at each day). The closed squares and dashed line represent the median values. EPSC amplitudes were measured at $V_{\mathrm{h}}$ $=-70 \mathrm{mV}$ unless the responses could not be clamped sufficiently to prevent the generation of action potentials. In these cases (some cells at P7 and P8), the cell was held at $-90 \mathrm{mV}$ and the amplitudes were normalized as if measured at $-70 \mathrm{mV}$ assuming that the current-voltage relationship of climbing fiber response is linear. Amplitudes of climbing fiber responses that escaped voltage control even at $-90 \mathrm{mV}$ were plotted at $2.0 \mathrm{nA}$.

$I^{2} / N_{\mathrm{c}}$ ) (with $V_{\mathrm{b}}$ being the baseline variance, $i_{\mathrm{u}}$ the single channel current, and $N_{c}$ the number of channels open at peak) using WinWCP (kindly made available by Dr. J. Dempster, University of Strathclyde, Glasgow, UK). Because the distribution was sometimes skewed, $\mathrm{N}_{\mathrm{c}}$ was in our hands not considered to be a reliable estimate for the actual number of channels open at peak (cf. Hartveit and Veruki, 2006). The number of channels involved in a climbing fiber response was estimated by dividing the peak current by the calculated unitary current. In addition, nonscaled nonstationary noise analysis was performed on the last $20 \%$ of the sample points. This analysis yields a linear relation with the unitary current as the slope (Hartveit and Veruki, 2006). The single channel conductance $\left(\gamma_{\mathrm{s}}\right)$ was calculated according to $\gamma_{\mathrm{s}}=i_{\mathrm{u}} /\left(V_{\mathrm{m}}-E_{\mathrm{AMPA}}\right)$, with $V_{\mathrm{m}}$ being the membrane potential $(-70 \mathrm{mV})$ and $E_{\mathrm{AMPA}}$ the reversal potential for AMPA receptors (set at $0 \mathrm{mV}$ ). The single channel conductances before and after LTP induction were compared using paired Student's $t$ test.

Statistical analysis. The normality of the distributions of all data sets was established using the Kolmogorov-Smirnov test. The averaged EPSC amplitudes before and after the induction were compared using paired Student's $t$ test. Unless stated otherwise, the other comparisons were made using the two-sided, unpaired Student's $t$ test. Throughout this manuscript, the level of significance was set at 0.05 .

\section{Results}

The developing climbing fiber-Purkinje cell connectivity Whole-cell voltage-clamp recordings from Purkinje cells were performed in cerebellar slices from rats at P4 through P11. Climbing fiber afferents were stimulated with extracellular electrodes in the granule cell layer as depicted in Figure $1 \mathrm{~A}$. Synaptic responses were identified as originating from climbing fiber stimulation when they showed both an all-or-none response and paired-pulse depression (Konnerth et al., 1990). The discrete EPSC amplitudes in the stimulus-response curves in Figure $1 B$ reflect the recruitment of three different climbing fiber inputs as the stimulation intensity at one position of the stimulation electrode was gradually increased (Konnerth et al., 1990). Each climbing fiber input is characterized by paired-pulse depression of the EPSC amplitude (Konnerth et al., 1990) (Fig. 1C). The independence of two climbing fiber inputs stimulated alternately at two different positions of the extracellular electrode was tested by the absence of paired-pulse depression (Fig. 1D).

During the first postnatal week Purkinje cells undergo a dramatic growth. Figure $2 A$ illustrates the rapid emergence of a complex apical dendritic tree. The morphological changes are paralleled by the partial elimination of surplus climbing fiber inputs onto Purkinje cells. Between P5 and P7 all cells tested had at least two climbing fiber inputs, whereas $\sim 90 \%$ of the Purkinje cells received three or more distinct climbing fiber inputs. After P7, the probability of finding multiply innervated Purkinje cells declines abruptly, reaching $\sim 30 \%$ at P10-P11 (Fig. 2 B).

We quantified the synaptic strength of the individual climbing fibers during this critical period of synaptic reorganization (Fig. $2 C-E)$. Using two stimulating electrodes placed in the granule cell layer, we carefully determined the synaptic strength and the in- 
A
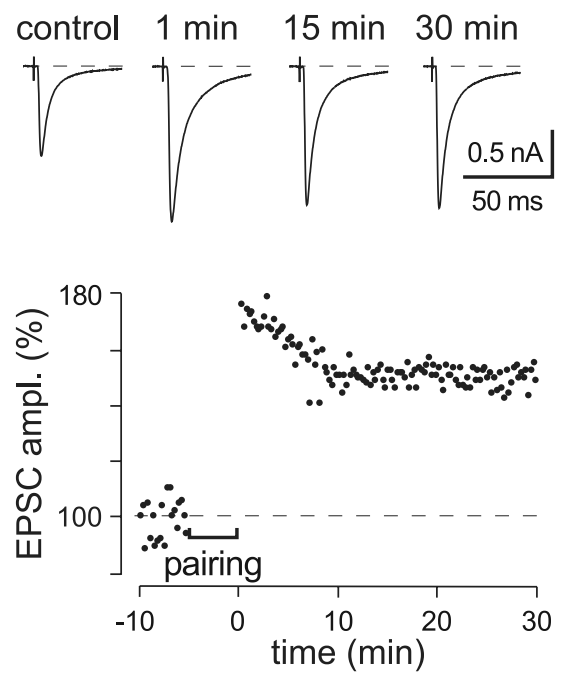

B

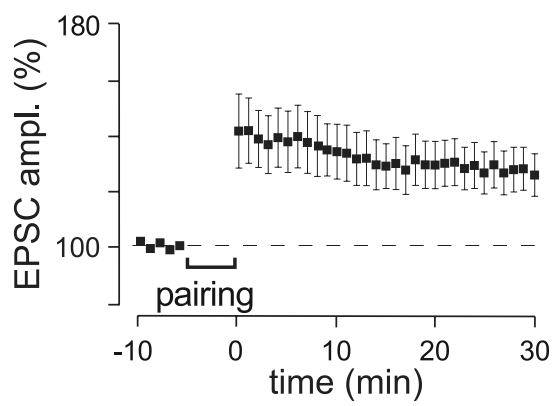

C

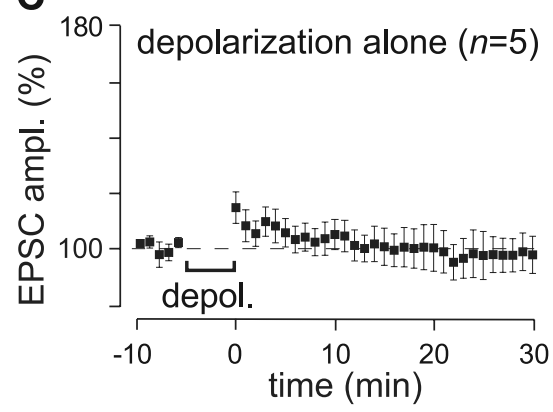

D

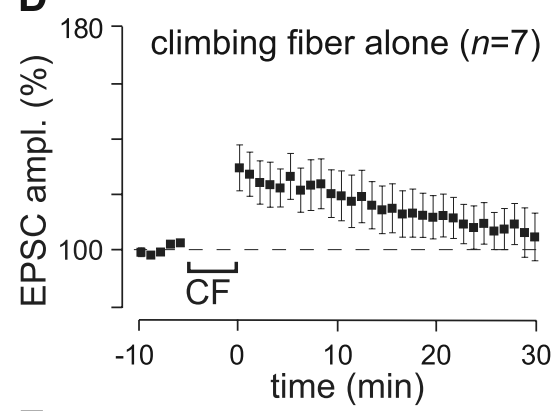

E

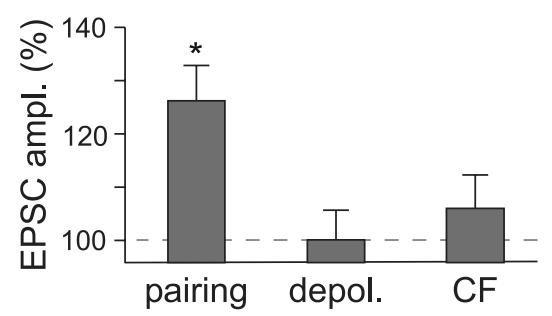

Figure 3. Homosynaptic LTP of climbing fiber synapses. $\boldsymbol{A}$, Representative experiment performed at P6. The plot represents the normalized amplitudes of climbing fiber EPSCs (evoked every $15 \mathrm{~s}$ ) against time before and after the pairing protocol. The top traces are averages of four consecutive EPSCs taken at the indicated time points. Pairing of postsynaptic depolarization (from -70 to $0 \mathrm{mV}$ ) with $4 \mathrm{~Hz}$ activation of the climbing fiber for 5 min induced a robust LTP. $\boldsymbol{B}$, Pooled data showing the result of pairinginduced LTP in P6-P8 Purkinje cells. Data were averaged per minute of recording (means \pm SEM, $n=19$ ). $\boldsymbol{C}, \boldsymbol{D}$, A sustained depolarization (from $-70-0 \mathrm{mV}$ for $5 \mathrm{~min}$ ) without climbing fiber stimulation $(\boldsymbol{C})$ or activation of the climbing fiber at $4 \mathrm{~Hz}$ for 5 min without postsynaptic depolarization (D) failed to induce LTP. $\boldsymbol{E}$, Bar graph summarizing the relative change in climbing fiber EPSC amplitudes for each experimental condition. The values represent the average change measured between 25 and $30 \mathrm{~min}$ after the end of the induction period ( ${ }^{*} p<0.05$, paired $t$ test).

dependence of the climbing fibers innervating one Purkinje cell and plotted the data for each postnatal day tested. The "largest" climbing fiber input of a given Purkinje cell generated EPSCs with amplitudes that were generally larger than $0.5 \mathrm{nA}$ (Fig. 2C). Remarkably, between P5, the first day of our analysis, and P8, there was on average a fourfold increase in the synaptic strength of the largest inputs $(0.50 \pm 0.14 \mathrm{nA}$ at $\mathrm{P} 5$ to $2.12 \pm 0.18 \mathrm{nA}$ at P8, means \pm SEM, $n \geq 10$ ) (Fig. $2 C$ ). The strengthening of the largest input took place even before the final elimination of the "smaller" inputs occurred (Fig. 2 B). In contrast, the strength of the weaker inputs was quite stable during the same period (Fig. $2 D, E$ ). The EPSCs evoked by the second and third strongest climbing fiber input did not change significantly between P5 and P8 (0.24 \pm $0.05-0.26 \pm 0.08 \mathrm{nA}$ and $0.13 \pm 0.02-0.21 \pm 0.04 \mathrm{nA}$, respectively; means \pm SEM; $p=0.8$ and 0.9 , respectively, ANOVA with Bonferroni's post-test, $n \geq 6$ ).

\section{Homosynaptic LTP of large climbing fiber inputs}

An increase of the EPSC amplitude over days as shown in Figure $2 C$ is consistent with the outgrowth of the large climbing fiber and the subsequent formation of new synaptic contacts. However, the amplitude of the climbing fiber EPSC does not only depend on the number of synaptic contacts with the Purkinje cells, but also on the synaptic strength of each contact site. In the cortex (e.g., in the visual system), it has been shown that the refinement of connectivity is based on a Hebbian potentiation of active synapses (Katz and Shatz, 1996; Zhang et al., 1998; Tao et al., 2001).

We tested the role of activitydependent synaptic plasticity in the developmental increase of EPSC amplitudes of the large climbing fiber input. Although the synaptic strength of climbing fibers is remarkably stable during low-frequency stimulation (Fig. 3A, B, control recordings), a robust potentiation of the responses can be induced by pairing a sustained postsynaptic depolarization with high-frequency climbing fiber activity [EPSC amplitude $20 \mathrm{~min}$ postinduction, $129 \pm 8 \%(n=19)$, means \pm SEM; $p=$ 0.0029 , paired $t$ test] (Fig. $3 A, B, E$ ). Climbing fiber EPSCs were strengthened immediately after the induction period and remained potentiated for at least $30 \mathrm{~min}$. In contrast, neither depolarization alone (Fig. 3C) nor climbing fiber stimulation alone (Fig. 3D) is sufficient to induce a sustained potentiation at the climbing fiber synapse [EPSC amplitude 20 min postinduction, $99 \pm 8 \%, n=5$, means \pm SEM; $p$ $=0.8$, paired $t$ test; and $112 \pm 8 \%(n=7)$, means \pm SEM, $p=0.3$, paired $t$ test, respectively] (Fig. 3E). These results suggested that a Hebbian mechanism, i.e., conjunctive presynaptic and postsynaptic activity, is necessary for the LTP of the climbing fiber input.

\section{Climbing fiber LTP is independent of}

\section{NMDA receptors}

The refinement of synaptic connections occurring during the critical periods in the developing cerebral cortex depends on NMDA receptor activity (Berardi et al., 2000). In the cerebellum, too, NMDA receptors are involved in the elimination of supernumerary climbing fibers occurring during the second postnatal week (Kakizawa et al., 2000). The neurons expressing these NMDA receptors most likely include the granule cells (Monyer et al., 1994), some types of GABAergic interneurons (Glitsch and Marty, 1999) and perhaps the Purkinje cells themselves, which were proposed to express NMDA receptors during early postnatal development (Krupa and Crepel, 1990).

We found that, as in the adult (Garthwaite et al., 1987), at the end of the first postnatal week climbing fiber EPSCs are not affected by bath application of the NMDA receptor antagonist APV $(100 \mu \mathrm{M})$ (Fig. 4A). This indicates that climbing fiber transmission to Purkinje cells is exclusively mediated by AMPA receptors. Furthermore, even in the absence of extracellular $\mathrm{Mg}^{2+}$ and at a depolarized holding potential $(-30 \mathrm{mV})$, brief application of NMDA failed to induce any current response in the soma as well 
as in the dendrites (Fig. 4B). In agreement with these findings, bath application of APV $(100 \mu \mathrm{M})$ did neither block nor change the time course of climbing fiber LTP (EPSC amplitudes 20 min postinduction, $124 \pm 6 \%$; $n=4$; means \pm SEM; $p=$ 0.0246 , paired $t$ test) (Fig. $4 C, D$ ). Thus, NMDA receptors neither contribute to synaptic transmission at the climbing fiber-Purkinje cell synapse nor are they required for LTP of the climbing fiber synaptic inputs.

\section{Climbing fiber LTP requires an elevation of postsynaptic \\ $\mathrm{Ca}^{2+}$ concentration}

In the hippocampus, the induction of both NMDA receptor-dependent and -independent forms of LTP require a rise in the postsynaptic $\mathrm{Ca}^{2+}$ concentration (Morgan and Teyler, 1999; Dineley et al., 2001). To test whether an increase in the intracellular $\mathrm{Ca}^{2+}$ concentration in the Purkinje cells is required for the induction of climbing fiber LTP, we included the fast $\mathrm{Ca}^{2+}$ chelator BAPTA into the intracellular solution. Whereas the climbing fibermediated EPSCs were unaffected by BAPTA (data not shown), the pairing of postsynaptic depolarization and highfrequency climbing fiber stimulation failed to induce LTP (Fig. 5A,B) under these conditions. The mean EPSC amplitude 20 min after induction was $95 \pm 11 \%$ of the baseline amplitude $(n=6$; means \pm SEM, $p=0.8$, paired $t$ test).

We studied climbing fiber-mediated $\mathrm{Ca}^{2+}$ responses in Purkinje cells in the whole-cell current-clamp mode using confocal $\mathrm{Ca}^{2+}$ imaging (Eilers et al., 1995). At P6 to P8, when Purkinje cells start to develop their characteristic apical dendrite (Fig. $2 \mathrm{~A}$ ) and climbing fiber LTP is operational, the largest climbing fiber usually elicits an EPSP that triggers one or more spikes. These suprathreshold responses are inevitably associated with $\mathrm{Ca}^{2+}$ influx into the soma and the dendrites of Purkinje cells. The dendritic transients are substantially larger in amplitude than the somatic ones (Fig. 5C, right traces). In contrast, the smaller climbing fiber inputs only evoked subthreshold EPSPs that were not associated with any detectable postsynaptic $\mathrm{Ca}^{2+}$ signals (Fig. $5 C$, left traces). Because the threshold for action potential generation critically depends on the membrane potential, the membrane resistance and the location of the synapses, the absolute size of climbing fiber inputs that produce suprathreshold responses could not be determined accurately. However, at resting membrane potential (approximately $-70 \mathrm{mV}$ ), climbing fiber EPSPs became suprathreshold when their corresponding EPSCs (as measured in the voltage-clamp mode) exceeded $0.3-0.7 \mathrm{nA}$. This value roughly corresponds to the upper limit of the smaller climbing fiber EPSC amplitudes (Fig. 2D,E), suggesting that individual small climbing fiber inputs fail to evoke both somatic and dendritic postsynaptic $\mathrm{Ca}^{2+}$ signals throughout develop$n=4)$.
C
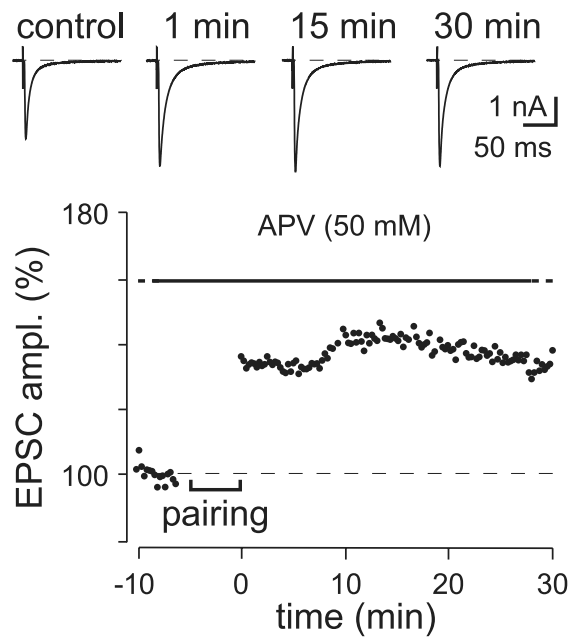

D

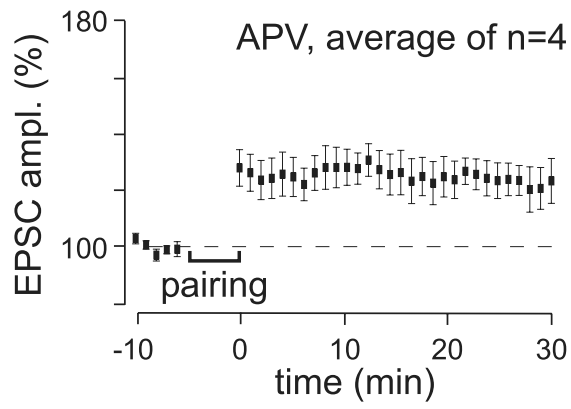

Figure 4. Climbing fiber LTP is NMDA receptor independent. $\boldsymbol{A}$, Climbing fiber EPSCs are mediated exclusively by AMPA from the control response. $\boldsymbol{B}$, Current traces obtained during brief application (10 ms) of AMPA or NMDA (both $100 \mu \mathrm{m}$ ) to the soma and to the dendrites of a Purkinje cell at P7. The extracellular solution was $\mathrm{Mg}^{2+}$-free and contained $10 \mathrm{~mm}$ glycine; $V_{\mathrm{h}}=$ LTP. Same experimental protocol as in Figure 3 is shown, as is a representative experiment $(\boldsymbol{C})$ and pooled data $(\boldsymbol{D} ;$ means \pm SEM,

ment. The large climbing fiber, however, always evokes $\mathrm{Ca}^{2+}$ transients after P5.

\section{Natural activity pattern of Purkinje cells and climbing fiber LTP}

Our original LTP protocol consisted of pairing climbing fiber stimulation with a prolonged ( $5 \mathrm{~min}$ ) depolarization of the Purkinje cell in the voltage-clamp mode (Fig. 3) while the Purkinje cells are filled with $\mathrm{Cs}^{+}$as the main cation. This protocol reliably produces a strong LTP. We assume that an important reason for this robustness is the fact that the prolonged depolarization causes a pronounced intracellular accumulation of $\mathrm{Ca}^{2+}$ ions, both in the dendrites and soma. The resulting accumulation of $\mathrm{Ca}^{2+}$ ions is likely to be much larger than under physiological conditions in which $\mathrm{Ca}^{2+}$ entry requires action potential firing (Fig. $5 C$ ). In the voltage-clamp condition, the synaptically evoked currents contribute only modestly to the total depolarizing drive that is dominated by the inward holding current that clamps the Purkinje cell to $0 \mathrm{mV}$. Thus, this stimulation protocol is not appropriate for a good distinction between the synaptic change occurring at the large climbing fiber inputs that produce action potentials and that occurring at the small ones that were found to 
A

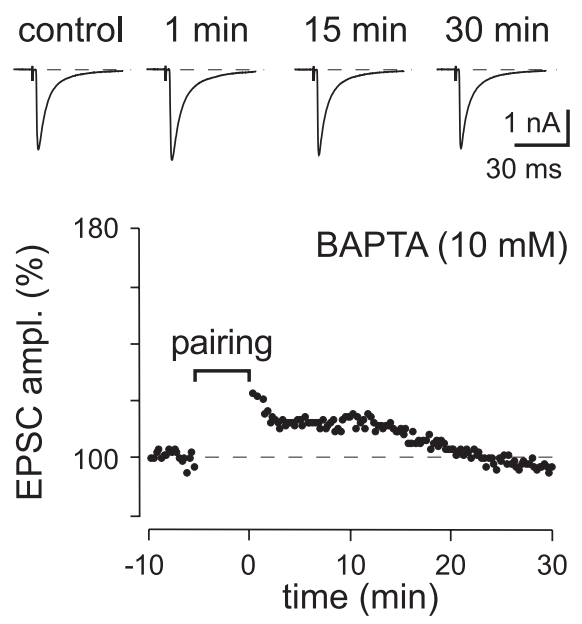

B

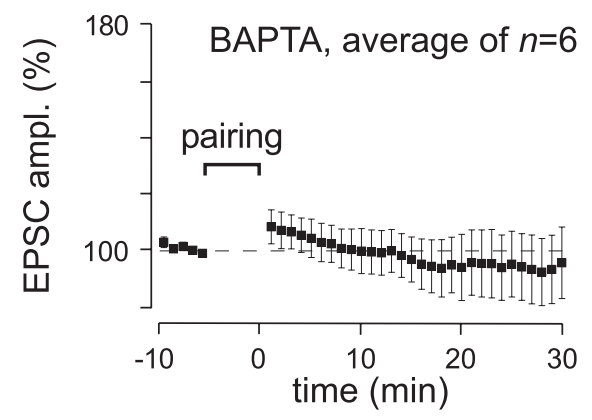

C
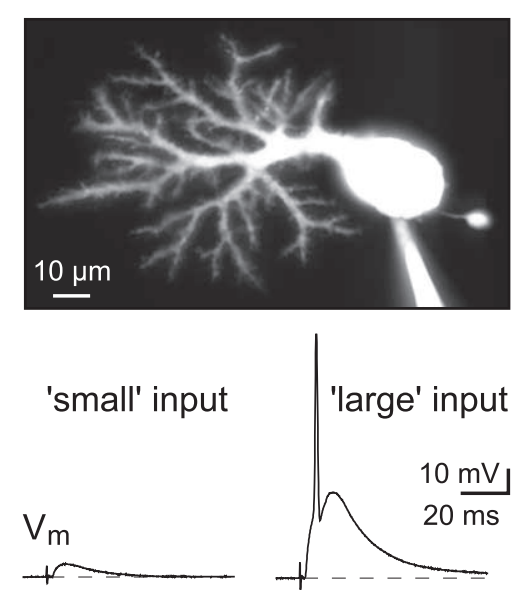

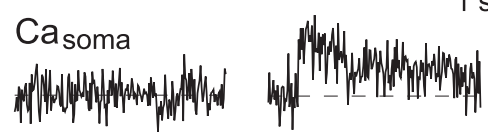

Figure 5. Induction of climbing fiber LTP depends on postsynaptic $\mathrm{Ca}^{2+} \cdot \boldsymbol{A}, \boldsymbol{B}$, Inclusion of the high-affinity $\mathrm{Ca}^{2+}$ chelator BAPTA (10 or $20 \mathrm{~mm}$ ) in the pipette solution blocks climbing fiber LTP. The same experimental protocol as in Figure 3 , as is a representative experiment $(\boldsymbol{A})$ and pooled data $(\boldsymbol{B} ;$ means $\pm \mathrm{SEM}, n=6)$. $\boldsymbol{C}$, Fluorescence images of a Purkinje cell at P8 loaded with Oregon Green BAPTA-1. The top traces $\left(V_{m}\right)$ represent EPSPs elicited by two distinct climbing fiber inputs, a small one (left) and the largest climbing fiber input detected in this Purkinje cell (right). The lower traces represent the corresponding simultaneously recorded $\mathrm{Ca}^{2+}$ transients measured in the dendrite (middle traces) and the soma (lower traces). Note that the small climbing fiber input failed to induce any $\mathrm{Ca}^{2+}$ increase.

be subthreshold (Figs. 5C, 6A, 7A). Therefore, we developed an induction protocol in current-clamp mode to test also the small climbing fiber inputs.

The initial attempts to induce LTP in current-clamp conditions in analogy to hippocampal LTP, using increasing stimulation frequencies, failed. Then we considered that at P7, Purkinje cells in vivo are spontaneously active during periods of several minutes (Woodward et al., 1969). The common firing pattern during these periods consists of doublet spikes, $25 \mathrm{~ms}$ apart, occurring at a frequency of around 3-4 Hz (Woodward et al., 1969). As a consequence, we adopted an induction protocol based on the naturally occurring doublet firing pattern. We produced a similar action potential doublet by injecting brief depolarizing current pulses into the Purkinje cell. This doublet was paired with the stimulation of climbing fiber as indicated in Figure $6 B$ (top). This paired stimulation was repeated 400 times at a frequency of $4 \mathrm{~Hz}$. The amplitude of the depolarizing current pulse was set to a level that generally caused the firing of one action potential (Fig. 6B, bottom). Failures did occur, however, and we accepted those experiments that had at least 650 action potentials.

We found that the application of this induction protocol to the large climbing fiber inputs produced LTP (Fig. 6C,D). The

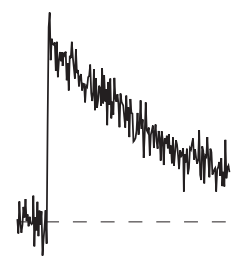

$0.1 \frac{\Delta \mathrm{F} / \mathrm{F}}{1 \mathrm{~s}}$

climbing fiber EPSC amplitude increased to $120 \pm 3 \%$ (20 min after induction; $n=$ 11 ; means \pm SEM, $p=0.0001$, paired $t$ test; P6-P9). The induction of LTP did not affect the paired-pulse depression $(44 \pm 4$ vs $43 \pm 3 \%$, before and after induction, respectively; $100 \mathrm{~ms}$ interval; means \pm SEM, $p=0.7$, paired $t$ test; $n=8$ ) (data not shown). During recordings with $<650$ action potentials, no LTP was observed $(107 \pm 4 \% ; 20 \mathrm{~min}$ after induction, means \pm SEM, $p=0.2$, paired $t$ test; $n=$ 12; P6-P9; $435 \pm 151$ action potentials during induction, means \pm SD) (data not shown).

\section{Climbing fiber-LTD of the "small" climbing fibers}

In contrast to the "large" climbing fiber inputs, "small" climbing fiber inputs are generally unable to evoke spikes in the postsynaptic Purkinje cell (Figs. 5C, 7A). Nevertheless we applied the same induction protocol also to the small inputs (Fig. $7 B)$. Again, we accepted only those experiments that showed $>650$ action potentials during the induction phase. Surprisingly, the small climbing fiber inputs were not strengthened by this protocol. In contrast, they produced a modest, but stable LTD (Fig. 7C,D). On average, the amplitude of the climbing fiber EPSC decreased to $76 \pm 7 \%$ (20 min after induction; means \pm SEM, $p=0.0051$, paired $t$ test; $n=8$; P6-P9). The number of action potentials evoked during the induction phase did not differ between the experiments on the large and small climbing fibers $(776 \pm$ 39 vs $765 \pm 39$ for the larger and the smaller climbing fiber inputs, respectively; means $\pm \mathrm{SD} ; p=0.6$, unpaired $t$ test). As was the case for climbing fiber LTP, the paired-pulse depression was not affected by climbing-fiber LTD ( $48 \pm 7$ vs $39 \pm 6$, before and after induction, respectively; $100 \mathrm{~ms}$ interval; means $\pm \mathrm{SEM} ; p=0.15$, paired $t$ test; $n=6$ ) (data not shown).

Finally, we constructed a scatter plot of all results from all cells that underwent the action potential-driven induction protocol. We found that in all climbing fiber inputs that had a control amplitude $<0.5 \mathrm{nA}$ the current-clamp induction protocol induced either no change or LTD. In contrast, the larger climbing fiber inputs always expressed LTP (Fig. 7D). Cluster analysis, when performed according to Ward's method using the control and postinduction climbing fiber EPSC amplitudes, confirmed the existence of two groups of climbing fibers, separated by the control amplitude of $0.5 \mathrm{nA}$ (Fig. 7E).

To address the mechanism underlying climbing fiber LTP, we analyzed the single channel properties of the AMPA receptors active during climbing fiber EPSCs using nonstationary noise analysis (Traynelis et al., 1993). For each experiment $(n=9)$, we averaged the EPSCs before and after LTP induction (using the current-clamp protocol illustrated in Fig. $6 B$ ). Next, we scaled all individual EPSCs to the peak of the mean EPSC (Fig. $8 \mathrm{~A}$ ). Peakscaled nonstationary noise analysis revealed that the single chan- 
nel conductance of the postsynaptic AMPA receptors increased (from $23 \pm 3$ to $32 \pm 3$ pS; means \pm SEM; $p=0.0154$, paired $t$ test; $n=9$ ) (Fig. $8 B$ ). The single channel conductance values estimated with peak-scaled nonstationary noise analysis were confirmed with conventional, nonscaled nonstationary noise analysis (see Materials and Methods) (data not shown). The number of postsynaptic receptors involved in the generation of the postsynaptic current was not significantly affected by LTP induction $(863 \pm 174$ vs $726 \pm 167$ open channels before and after LTP induction, respectively; means \pm SEM; $p=0.3$, paired $t$ test $n=9$ ) (data not shown). These results strongly indicate that not only the induction of climbing fiber LTP, but also its expression is postsynaptic.

\section{Discussion}

During development, the synaptic connections between climbing fibers and Purkinje cells undergo a dramatic rearrangement. Initially, several climbing fibers innervate each Purkinje cell, but this changes within two-three weeks to a oneto-one relationship. During this rearrangement, a single large climbing fiber transiently coexists with several smaller climbing fiber inputs. Our results demonstrate the presence of a new form of fiberspecific LTP in climbing fiber-Purkinje cell synapses during this period of synaptic rearrangement. Remarkably, this LTP is expressed exclusively at the largest inputs, the ones that most likely represent the "winner" climbing fibers that eventually survive into adulthood. In contrast, the weak synaptic inputs, those that are presumably eliminated, are not potentiated. Some of these express even LTD. We found that the induction of LTP was particularly robust in conditions of voltageclamp recordings, when climbing fiber stimulation was paired with a prolonged depolarization of the postsynaptic Purkinje cell. Under more physiological current-clamp conditions, we were able to reliably evoke LTP only when conjunctively stimulating Purkinje cells and the afferent climbing fiber with a pattern that is characteristic for the activity of immature Purkinje cells in vivo (Woodward et al., 1969). Despite previous suggestions, NMDA receptor channels did not contribute to synaptic transmission at immature climbing fibers and were also not involved in the induction of LTP. Instead, LTP required a strong postsynaptic $\mathrm{Ca}^{2+}$ signal that was generated primarily by $\mathrm{Ca}^{2+}$ entry through activated voltage-gated $\mathrm{Ca}^{2+}$ channels.

In this study, we focused on an early stage of development, ranging from $\mathrm{P} 4$ to $\sim \mathrm{P} 10$, during which climbing fiber-Purkinje cell synapses undergo a dramatic rearrangement (Fig. 2). Between P4 and P7, the number of multiple climbing fibers per Purkinje cell reaches its maximum (mostly three to six) and starts to decline thereafter (Crepel et al., 1981; Mariani and Changeux,
C control

$20 \min$
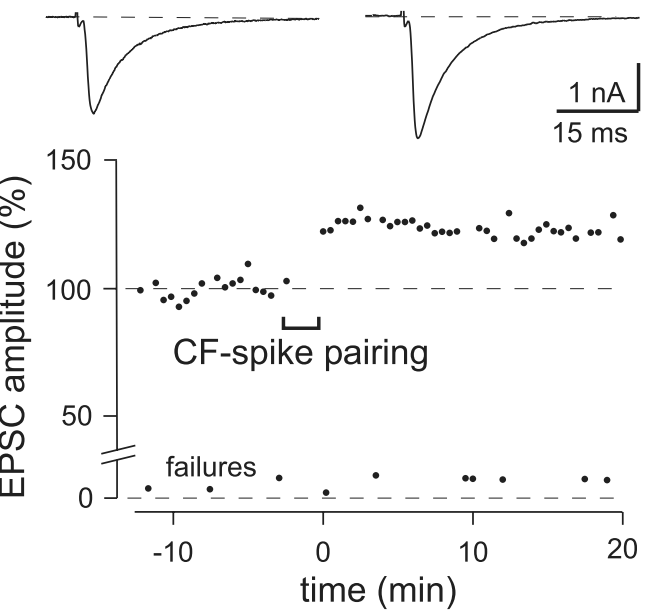

D

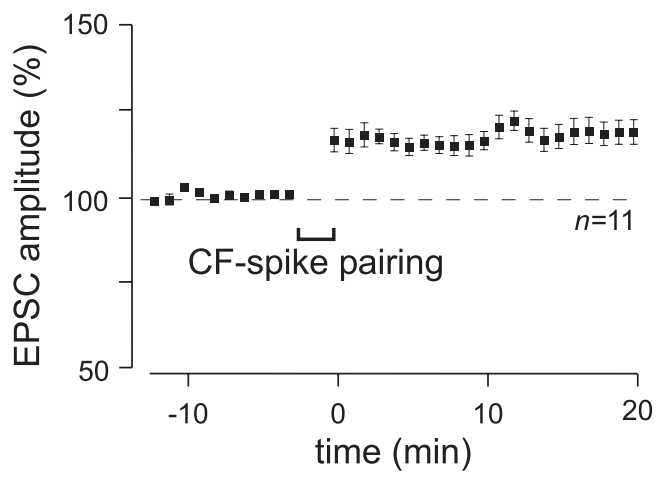

Figure 6. Action potential-dependent LTP of large climbing fiber inputs. $\boldsymbol{A}$, The largest climbing fiber input of a given Purkinje voltage-clamp is shown on the right. $\boldsymbol{B}$, Protocol for the induction of synaptic plasticity consisting of the pairing of climbing fiber (CF) activity with spike activity in the postsynaptic Purkinje cell (PC). In the current-clamp mode, the Purkinje cell was kept at a doublet depolarizing pulse exceeding the action potential threshold. Top, Current-clamp recording of a Purkinje cell during the baseline and postinduction phase were recorded in voltage-clamp mode ( $\mathrm{V}=-70 \mathrm{mV})$. The top traces are averages of fou consecutive EPSCs taken at the indicated time points. D, Pooled data showing the result of pairing-induced LTP of large climbing fiber inputs in P6 -P9 Purkinje cells. Data were averaged per minute of recording (means \pm SEM; $n=11$ ).

1981; Hashimoto and Kano, 2005; Scelfo and Strata, 2005). In parallel, one climbing fiber input is becoming gradually stronger (Hashimoto and Kano, 2003). It is believed that this synaptic strengthening involves an increase in the number of functional release sites in the presynaptic terminals (Hashimoto and Kano, 2003). Moreover, the larger climbing fibers powerfully expand their innervation territory on the growing PC dendrite. It is assumed that whereas the large climbing fibers are the ones that persist into adulthood, the smaller climbing fibers become atrophic, retract and eventually disappear (Sugihara, 2006). This process of elimination of redundant climbing fiber afferents lasts until the end of the third week of postnatal development (Hashimoto and Kano, 2005).

Previous work demonstrated that although the earliest phase of developmental climbing fiber elimination is independent of parallel fiber activity, the subsequent phase of developmental elimination of redundant climbing fibers depends on the formation of a functional parallel fiber synaptic input to the Purkinje 
A

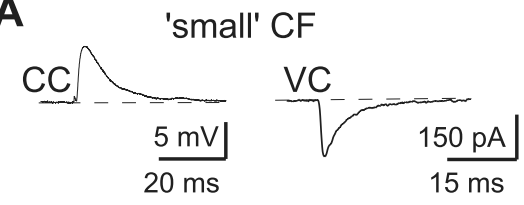

B CF-spike pairing

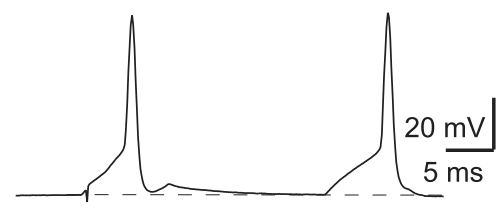

C
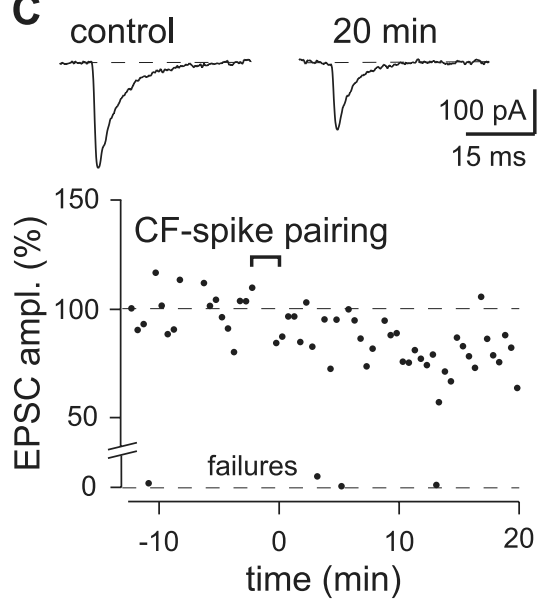

D
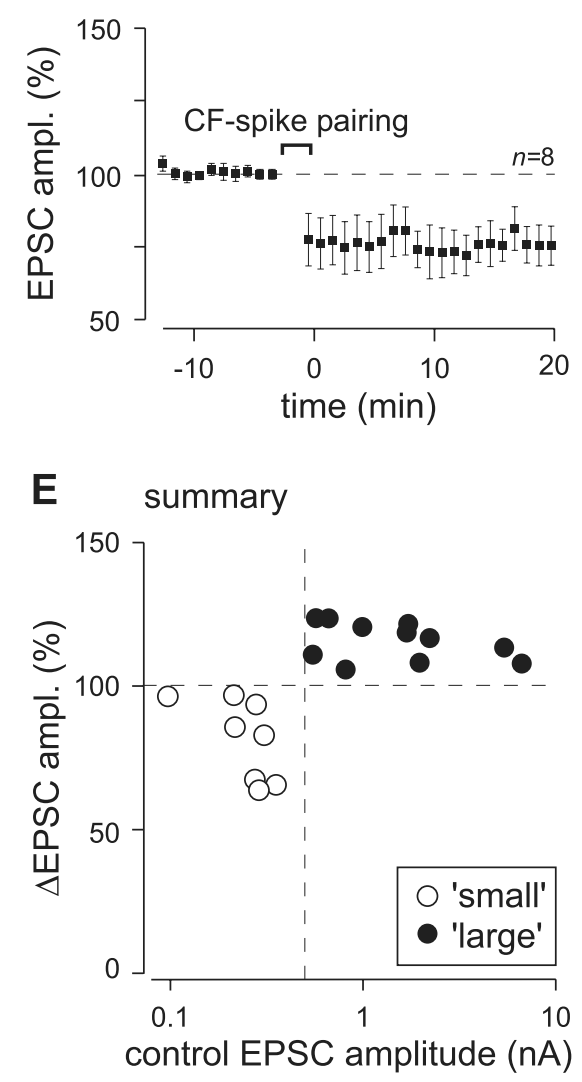

Figure 7. Activity-dependent scaling of climbing fiber inputs. $\boldsymbol{A}$, Small climbing fibers as a rule failed to induce action potentials. After stimulation in current-clamp mode, they induce subthreshold EPSPs (left trace). The corresponding current trace under voltage-clamp is shown on the right. $\boldsymbol{B}$, The same induction protocol as illustrated in Figure $6 B$ reliably elicited action potentials in the postsynaptic Purkinje cell. C, LTD of a small climbing fiber input after the action potential-dependent induction protocol as depicted in Figure $6 B$. The baseline and postinduction phase were recorded in voltage-clamp mode $\left(V_{\mathrm{h}}=-70 \mathrm{mV}\right)$. The top traces are averages of four consecutive EPSCs taken at the indicated time points. $\boldsymbol{D}$, Pooled data showing the result of pairinginduced LTD of small climbing fiber inputs in P6 -P9 Purkinje cells. Data were averaged per minute of recording (means \pm SEM; $n=8$ ). The dashed vertical line marks the amplitude of $0.5 \mathrm{nA}$. $\boldsymbol{E}$, Pairing of postsynaptic action potential firing with climbing fiber stimulation had different effects on small and large climbing fiber inputs. Synapses of small climbing fibers were depressed, whereas those of large climbing fibers were strengthened. The climbing fiber inputs having control amplitudes larger than $0.5 \mathrm{nA}$ showed LTP. The existence of two separate clusters was confirmed by cluster analysis using Ward's method.

cells (Crepel et al., 1981; Rabacchi et al., 1992; Scelfo and Strata, 2005). Parallel fiber synapses, through activation of the orphan glutamate receptor GluR $\delta 2$ by an unknown mechanism, confine the climbing fiber innervation sites to the proximal part of the Purkinje cell dendrite (Hashimoto et al., 2001). During the third postnatal week, the final stage of developmental climbing fiber synapse elimination, activation of NMDA receptors on mossy fiber-to-granule cell synapses plays an important role (Rabacchi et al., 1992; Kakizawa et al., 2000). This NMDA receptormediated activity of granule cells is required for the activation of mGluR1 (Kano et al., 1997) at parallel fiber-Purkinje cell synapses. The action of mGluR1 on climbing fiber synapse elimination is exerted through its downstream effectors $\mathrm{G} \alpha$ (the $\alpha$-subunit of the heterotrimeric GTP-binding protein $\mathrm{G}_{\mathrm{q}}$ ) (Offermanns et al., 1997), PLC $\beta 4$ (phospholipase C $\beta 4$ ) (Kano et al., 1998), and PKC $\gamma$ (protein kinase C $\gamma$ ) (Kano et al., 1995). In addition, also neurotrophins have recently been implicated in the maturation of the climbing fiber-Purkinje cell synapses (Bosman et al., 2006; Johnson et al., 2007).

Whereas the late stages of climbing fiber synapse elimination are relatively well understood, the mechanisms controlling the early developmental stage (until $\sim$ P10) remained unclear. Our results indicate that during this early period, the activity of the climbing fibers themselves may reinforce the segregation in large climbing fibers prone to survive into adulthood and smaller climbing fibers that will be lost. Why are small and large climbing fiber inputs differentially affected by the same stimulation paradigm? We hypothesize that this is related to subcellular differences in intracellular $\mathrm{Ca}^{2+}$ concentration. The soma of the Purkinje cell receives less $\mathrm{Ca}^{2+}$ influx than the dendrite after action potential firing, as illustrated in Figure $5 C$. This is because of the nonuniform distribution of voltage-activated $\mathrm{Ca}^{2+}$ channels with their greater density in the dendrite of Purkinje cells than in the soma (Usowicz et al., 1992; Llano et al., 1994) and, perhaps more importantly, to the larger surface-tovolume ratio of the dendrite compared with the soma (Eilers et al., 1995). The small climbing fiber inputs, which are mainly confined to the soma (Sugihara, 2005) will experience lower $\mathrm{Ca}^{2+}$ levels during spontaneous action potential activity. Moreover, these synaptic inputs produce predominantly subthreshold EPSPs that are not associated with intracellular $\mathrm{Ca}^{2+}$ signals. In contrast, the large climbing fiber inputs, corresponding to the more mature type of climbing fibers that form dense swellings also on the proximal dendrite (Sugihara, 2005), will experience the large $\mathrm{Ca}^{2+}$ transients occurring in dendrites. As in various other brain regions, the polarity of the synaptic gain change during the induction of synaptic plasticity may depend also at climbing fiber-Purkinje cell synapses on the relative magnitude of the $\mathrm{Ca}^{2+}$ increase (Cho et al., 2001; Lisman et al., 2002).

Next to the requirement of a postsynaptic $\mathrm{Ca}^{2+}$ increase, we found two other clear indications that the mechanism underlying climbing fiber LTP is largely postsynaptic. First, there is no change in the paired-pulse depression of climbing fiber EPSCs after LTP or LTD induction (data not shown). Second, we provide evidence suggesting that the single channel conductance of the postsynaptic AMPA receptors increases during LTP (Fig. 8). The amount of increase in single channel conductance can by itself explain the enhancement of EPSC amplitudes during LTP. A similar increase in the AMPA receptor single channel conductance has been previously reported for LTP in the hippocampal area CA1 (Benke et al., 1998). Although an increase in the single channel conductance of AMPA receptors could be explained by an increase in the glutamate concentration in the synaptic cleft (Rosenmund et al., 1998; Smith and Howe, 2000), this does probably not occur in juvenile climbing fiber synapses. Under normal conditions, there is multiple vesicle release by climbing fiber terminals, resulting in a glutamate concentration that nearly saturates the postsynaptic AMPA receptors (Harrison and Jahr, 2003). Thus, even if a further increase in glutamate release would 
A

\section{control}

\section{post-induction}
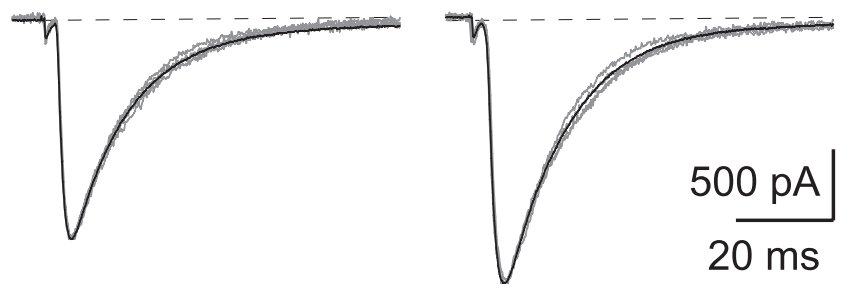

B

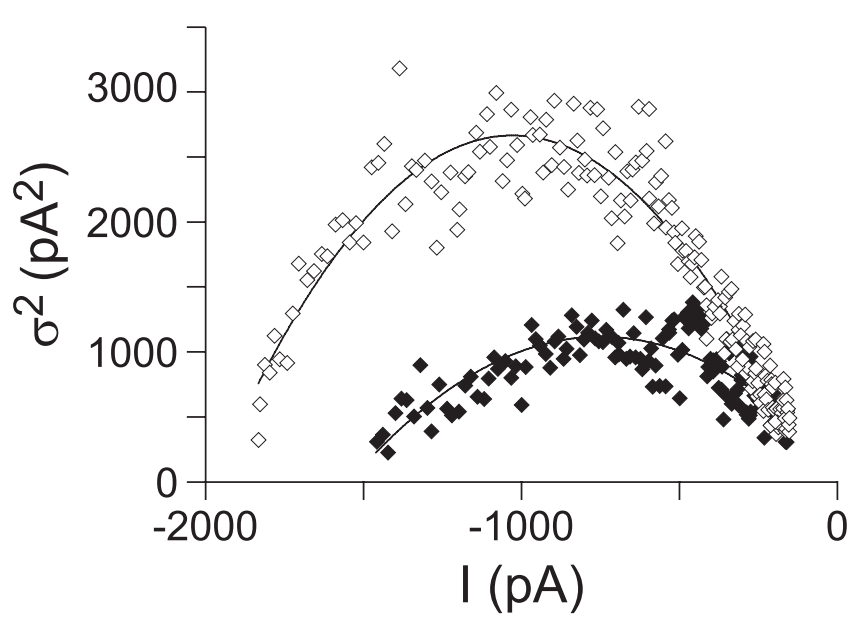

Figure 8. The single channel conductance of the postsynaptic AMPA receptors increases during LTP. A, Comparison of four, peak-scaled individual EPSCS with the mean EPSC before (left) and after (right) LTP induction in a representative experiment. The current scale bar illustrates the size of the mean EPSCS. B, For each sample point, the mean squared difference between the individual EPSCs and the mean EPSC $s$ was plotted against the current of the mean EPSC. The resulting distributions were fit using a parabolar function. Shown are the distributions of the preinduction (closed symbols) and postinduction (open symbols) phase of the same experiment as depicted in $\boldsymbol{A}$. The single-channel conductances were derived from these fits. $0 \mathrm{n}$ average, the single channel conductance increased from $23 \pm 3$ pS before LTP induction to $32 \pm 3 \mathrm{pS}$ afterward (means \pm SEM, $p=0.0154$; paired $t$ test; $n=9$ ).

occur, this would not lead to an increase in the single channel conductance of the postsynaptic AMPA receptors. Therefore, it is more likely that the mechanism underlying the increase in the conductance levels of postsynaptic AMPA receptors is postsynaptic, for instance via a $\mathrm{Ca}^{2+} /$ calmodulin-dependent protein kinase II-dependent phosphorylation of these AMPA receptors (Barria et al., 1997).

Together, our results suggest a role of homosynaptic activitydependent synaptic plasticity in developmental climbing fiber rewiring that is distinctly different from the earlier suggestion that LTD of (the persisting) climbing fibers is involved in developmental climbing fiber elimination (Hansel and Linden, 2000). Our results suggest that an early form of LTD, expressed exclusively at the weak climbing fiber synapses, contributes to the activity dependent weakening of these inputs, which are bound to eventually disappear. On the other, the largest and persisting climbing fiber synapses express initially homosynaptic LTP. Thus, LTP may further strengthen the already large synapses by, perhaps, contributing toward the formation of new synaptic con- tacts on the growing dendritic tree. This process will probably stop at the beginning of the third postnatal week, when the morphology of Purkinje cells nearly reaches its final state. Interestingly, this is also the stage at which mice begin to show complex motor behaviors, like running (Glynn et al., 2007). From that stage on, mutants that retain multiple climbing fiber innervation during adulthood, show deficient parallel fiber LTD and impaired motor learning (Aiba et al., 1994; Ichise et al., 2000; Hansel et al., 2006). We suggest that around the onset of the third postnatal week, the persisting climbing fiber-Purkinje cell synapses switch from activity-dependent LTP to LTD. By this time, Purkinje cells are required for proper motor coordination. Climbing fiber LTD may then contribute to the cerebellar functions needed for proper motor control through mechanisms that were first proposed by Hansel and Linden (2000).

\section{References}

Aiba A, Kano M, Chen C, Stanton ME, Fox GD, Herrup K, Zwingman TA, Tonegawa S (1994) Deficient cerebellar long-term depression and impaired motor learning in mGluR1 mutant mice. Cell 79:377-388.

Albus JS (1971) A theory of cerebellar function. Math Biosci 10:25-61.

Barria A, Muller D, Derkach V, Griffith LC, Soderling TR (1997) Regulatory phosphorylation of AMPA-type glutamate receptors by CaM-KII during long-term potentiation. Science 276:2042-2045.

Benke TA, Lüthi A, Isaac JTR, Collingridge GL (1998) Modulation of AMPA receptor unitary conductance by synaptic activity. Nature 393:793-797.

Berardi N, Pizzorusso T, Maffei L (2000) Critical periods during sensory development. Curr Opin Neurobiol 10:138-145.

Bliss TVP, Collingridge GL (1993) A synaptic model of memory: long-term potentiation in the hippocampus. Nature 361:31-39.

Bosman LWJ, Hartmann J, Barski JJ, Lepier A, Noll-Hussong M, Reichardt LF, Konnerth A (2006) Requirement of TrkB for synapse elimination in developing Purkinje cells. Brain Cell Biol 35:87-101.

Boyden ES, Katoh A, Raymond JL (2004) Cerebellum-dependent learning: the role of multiple plasticity mechanisms. Annu Rev Neurosci 27:581-609.

Cho K, Aggleton JP, Brown MW, Bashir ZI (2001) An experimental test of the role of postsynaptic calcium levels in determining synaptic strength using perirhinal cortex of rat. J Physiol (Lond) 532:459-466.

Coesmans M, Weber JT, De Zeeuw CI, Hansel C (2004) Bidirectional parallel fiber plasticity in the cerebellum under climbing fiber control. Neuron 44:691-700.

Crepel F, Delhaye-Bouchaud N, Dupont JL (1981) Fate of the multiple innervation of cerebellar Purkinje cells by climbing fibers in immature control, X-irradiated and hypothyroid rats. Brain Res Dev Brain Res 1:59-71.

Dineley KT, Weeber EJ, Atkins C, Adams JP, Anderson AE, Sweatt JD (2001) Leitmotifs in the biochemistry of LTP induction: amplification, integration and coordination. J Neurochem 77:961-971.

Eccles JC, Llinás R, Sasaki K (1966) The excitatory synaptic action of climbing fibres on the Purkinje cells of the cerebellum. J Physiol (Lond) 182:268-296.

Eilers J, Augustine GJ, Konnerth A (1995) Subthreshold synaptic $\mathrm{Ca}^{2+}$ signalling in fine dendrites and spines of cerebellar Purkinje neurons. Nature 373:155-158.

Ekerot CF, Kano M (1985) Long-term depression of parallel fibre synapses following stimulation of climbing fibres. Brain Res 342:357-360.

Garthwaite G, Yamini Jr B, Garthwaite J (1987) Selective loss of Purkinje and granule cell responsiveness to N-methyl-D-aspartate in rat cerebellum during development. Brain Res Dev Brain Res 433:288-292.

Glitsch M, Marty A (1999) Presynaptic effects of NMDA in cerebellar Purkinje cells and interneurons. J Neurosci 19:511-519.

Glynn D, Sizemore RJ, Morton AJ (2007) Early motor development is abnormal in complexin 1 knockout mice. Neurobiol Dis 25:483-495.

Goda Y, Davis GW (2003) Mechanisms of synapse assembly and disassembly. Neuron 40:243-264.

Hansel C, Linden DJ (2000) Long-term depression of the cerebellar climbing fiber-Purkinje neuron synapse. Neuron 26:473-482.

Hansel C, De Jeu M, Belmeguenai A, Houtman SH, Buitendijk GHS, Andreev 
D, De Zeeuw CI, Elgersma Y (2006) $\alpha$ CaMKII Is essential for cerebellar LTD and motor learning. Neuron 51:835-843.

Harrison J, Jahr CE (2003) Receptor occupancy limits synaptic depression at climbing fiber synapses. J Neurosci 23:377-383.

Hartveit E, Veruki ML (2006) Studying properties of neurotransmitter receptors by non-stationary noise analysis of spontaneous synaptic currents. J Physiol (Lond) 574:751-785.

Hashimoto K, Kano M (2003) Functional differentiation of multiple climbing fiber inputs during synapse elimination in the developing cerebellum. Neuron 38:785-796.

Hashimoto K, Kano M (2005) Postnatal development and synapse elimination of climbing fiber to Purkinje cell projection in the cerebellum. Neurosci Res 53:221-228.

Hashimoto K, Ichikawa R, Takechi H, Inoue Y, Aiba A, Sakimura K, Mishina M, Hashikawa T, Konnerth A, Watanabe M, Kano M (2001) Roles of glutamate receptor $\delta 2$ subunit (GluR $\delta 2)$ and metabotropic glutamate receptor subtype 1 (mGluR1) in climbing fiber synapse elimination during postnatal cerebellar development. J Neurosci 21:9701-9712.

Ichise T, Kano M, Hashimoto K, Yanagihara D, Nakao K, Shigemoto R, Katsuki M, Aiba A (2000) mGluR1 in cerebellar Purkinje cells essential for long-term depression, synapse elimination, and motor coordination. Science 288:1832-1835.

Ito M (2000) Mechanisms of motor learning in the cerebellum. Brain Res 886:237-245.

Ito M (2001) Cerebellar long-term depression: characterization, signal transduction, and functional roles. Physiol Rev 81:1143-1195.

Ito M (2006) Cerebellar circuitry as a neuronal machine. Prog Neurobiol 78:272-303.

Johnson EM, Craig ET, Yeh HH (2007) TrkB is necessary for pruning at the climbing fibre-Purkinje cell synapse in the developing murine cerebellum. J Physiol (Lond) 582:629-646.

Kakizawa S, Yamasaki M, Watanabe M, Kano M (2000) Critical period for activity-dependent synapse elimination in developing cerebellum. J Neurosci 20:4954-4961.

Kano M, Hashimoto K, Chen C, Abeliovich A, Aiba A, Kurihara H, Watanabe $\mathrm{M}$, Inoue $\mathrm{Y}$, Tonegawa S (1995) Impaired synapse elimination during cerebellar development in PKC $\gamma$ mutant mice. Cell 83:1223-1231.

Kano M, Hashimoto K, Kurihara H, Watanabe M, Inoue Y, Aiba A, Tonegawa S (1997) Persistent multiple climbing fiber innervation of cerebellar Purkinje cells in mice lacking mGluR1. Neuron 18:71-79.

Kano M, Hashimoto K, Watanabe M, Kurihara H, Offermanns S, Jiang H, Wu Y, Jun K, Shin HS, Inoue Y, Simon MI, Wu D (1998) Phospholipase c $\beta 4$ is specifically involved in climbing fiber synapse elimination in the developing cerebellum. Proc Natl Acad Sci USA 95:15724-15729.

Katz LC, Shatz CJ (1996) Synaptic activity and the construction of cortical circuits. Science 274:1133-1138.

Koekkoek SKE, Hulscher HC, Dortland BR, Hensbroek RA, Elgersma Y, Ruigrok TJH, De Zeeuw CI (2003) Cerebellar LTD and learningdependent timing of conditioned eyelid responses. Science 301:1736-1739.

Konnerth A, Llano I, Armstrong CM (1990) Synaptic currents in cerebellar Purkinje cells. Proc Natl Acad Sci USA 87:2662-2665.

Krakauer JW, Shadmehr R (2006) Consolidation of motor memory. Trends Neurosci 29:58-64.

Krupa M, Crepel F (1990) Transient sensitivity of rat cerebellar Purkinje cells to $N$-methyl-D-aspartate during development. A voltage clamp study in in vitro slices. Eur J Neurosci 2:312-316.

Larramendi EM, Victor T (1967) Synapses on the Purkinje cell spines in the mouse. An electronmicroscopic study. Brain Res 5:15-30.

Lev-Ram V, Wong ST, Storm DR, Tsien RY (2002) A new form of cerebellar long-term potentiation is postsynaptic and depends on nitric oxide but not cAMP. Proc Natl Acad Sci USA 99:8389-8393.

Lisman J, Schulman H, Cline H (2002) The molecular basis of CaMKII function in synaptic and behavioural memory. Nat Rev Neurosci 3:175-190.

Llano I, DiPolo R, Marty A (1994) Calcium-induced calcium release in cerebellar Purkinje cells. Neuron 12:663-673.

Llinás R, Bloedel JR, Hillman DE (1969) Functional characterization of neuronal circuitry of frog cerebellar cortex. J Neurophysiol 32:847-870.

Mariani J, Changeux JP (1981) Ontogenesis of olivocerebellar relationships. I. Studies by intracellular recordings of the multiple innervation of Purkinje cells by climbing fibers in the developing rat cerebellum. J Neurosci 1:696-702.

Marr D (1969) A theory of cerebellar cortex. J Physiol (Lond) 202:437-470.

Monyer H, Burnashev N, Laurie DJ, Sakmann B, Seeburg PH (1994) Developmental and regional expression in the rat brain and functional properties of four NMDA receptors. Neuron 12:529-540.

Morgan SL, Teyler TJ (1999) VDCCs and NMDARs underlie two forms of LTP in CA1 hippocampus in vivo. J Neurophysiol 82:736-740.

Napper RMA, Harvey RJ (1988) Number of parallel fiber synapses on an individual Purkinje cell in the cerebellum of the rat. J Comp Neurol 274:168-177.

Nicoll RA (2003) Expression mechanisms underlying long-term potentiation: a postsynaptic view. Philos Trans R Soc Lond B Biol Sci 358:721-726.

Offermanns S, Hashimoto K, Watanabe M, Sun W, Kurihara H, Thompson RF, Inoue Y, Kano M, Simon MI (1997) Impaired motor coordination and persistent multiple climbing fiber innervation of cerebellar Purkinje cells in mice lacking $\mathrm{G} \alpha_{\mathrm{q}}$. Proc Natl Acad Sci USA 94:14089-14094.

Rabacchi S, Bailly Y, Delhaye-Bouchaud N, Mariani J (1992) Involvement of the $\mathrm{N}$-methyl D-aspartate (NMDA) receptor in synapse elimination during cerebellar development. Science 256:1823-1825.

Rosenmund C, Legendre P, Westbrook GL (1992) Expression of NMDA channels on cerebellar Purkinje cells acutely dissociated from newborn rats. J Neurophysiol 68:1901-1905.

Rosenmund C, Stern-Bach Y, Stevens CF (1998) The tetrameric structure of a glutamate receptor channel. Science 280:1596-1599.

Salin PA, Malenka RC, Nicoll RA (1996) Cyclic AMP mediates a presynaptic form of LTP at cerebellar parallel fiber synapses. Neuron 16:797-803.

Scelfo B, Strata P (2005) Correlation between multiple climbing fibre regression and parallel fibre response development in the postnatal mouse cerebellum. Eur J Neurosci 21:971-978.

Sigworth FJ (1980) The variance of sodium current fluctuations at the node of Ranvier. J Physiol (Lond) 307:97-129.

Smith TC, Howe JR (2000) Concentration-dependent substate behavior of native AMPA receptors. Nat Neurosci 3:992-997.

Sugihara I (2005) Microzonal projection and climbing fiber remodeling in single olivocerebellar axons of newborn rats at postnatal days $4-7$. J Comp Neurol 487:93-106.

Sugihara I (2006) Organization and remodeling of the olivocerebellar climbing fiber projection. Cerebellum 5:15-22.

Tao HW, Zhang LI, Engert F, Poo MM (2001) Emergence of input specificity of LTP during development of retinotectal connections in vivo. Neuron 31:569-580.

Traynelis SF, Silver RA, Cull-Candy SG (1993) Estimated conductance of glutamate receptor channels activated during EPSCs at the cerebellar mossy fiber-granule cell synapse. Neuron 11:279-289.

Usowicz MM, Sugimori M, Cherksey B, Llinás R (1992) P-type calcium channels in the somata and dendrites of adult cerebellar Purkinje cells. Neuron 9:1185-1199.

Woodward DJ, Hoffer BJ, Lapham LW (1969) Postnatal development of electrical and enzyme histochemical activity in Purkinje cells. Exp Neurol 23:120-139.

Zhang LI, Tao HW, Holt CE, Harris WA, Poo MM (1998) A critical window for cooperation and competition among developing retinotectal synapses. Nature 395:37-44. 